\title{
How can we promote co-creation in communities? The perspective of health promoting professionals in four European countries
}

Emily Joan Darlington, Gemma Pearce, Teresa Vilaça, Julien Masson, Sandie Bernard, Zélia Anastácio, Paul Magee, Frants Christensen, Henriette Hansen, and Graça S. Carvalho

Author Accepted Manuscript (postprint) PDF deposited in Coventry University's Repository

Original citation:

Darlington, E.J., Pearce, G., Vilaça, T. Masson, J. Bernard, S., Anastácio, Z., Magee, P., Christensen, F., Hansen, H. and Carvalho, G.S. (2021), "How can we promote cocreation in communities? The perspective of health promoting professionals in four European countries", Health Education (In Press)

https://doi.org/10.1108/HE-02-2021-0033

DOI 10.1108/HE-02-2021-0033

ISSN $0965-4283$

Publisher: Emerald

The accepted manuscript is distributed under a Creative Commons Non-Commercial International Licence 4.0.

Copyright $(\subset$ and Moral Rights are retained by the author(s) and/ or other copyright owners. A copy can be downloaded for personal non-commercial research or study, without prior permission or charge. This item cannot be reproduced or quoted extensively from without first obtaining permission in writing from the copyright holder(s). The content must not be changed in any way or sold commercially in any format or medium without the formal permission of the copyright holders. 


\section{Title: How can we promote co-creation in communities? The perspective of health promoting professionals in four European countries}

community development - competence - creative thinking - health promotion - professionnals training

Authors:

Darlington, E., Pearce, G. Masson, J., Bernard, S., Vilaça, T., Anastácio, Z., Magee, P., Christensen, F. Hansen, H., Carvalho, G.

Accepted for publication in Health Education on $15^{\text {th }}$ Oct 2021.

Acknowledgements: The authors wish to Acknowledge Helle Hende Stermose, Arnaud Zohou, Françoise Poyet, Olivier Morin, Marianne Staal Storgaard, and Wendy Clyne for their contribution to data collection. 


\section{ABSTRACT}

Design/methodology/approach

Co-creation could contribute to building community capacity to promote health. Professional development is key to support co-creative practices. Participants were professionals in a position to promote co-creation processes in health promoting welfare settings across Denmark, Portugal, France, and United Kingdom. An overarching unstructured topic guide was used within interviews, focus groups, questionnaires, and creative activities.

Purpose

The aim was to identify the competencies professionals need to promote co-creation engagement within communities.

Findings

The need to develop competencies to promote co-creation was high across all countries. Creating a common understanding of co-creation and the processes involved to increase inclusivity, engagement, and shared understanding was also necessary. Competencies included: how to run co-creation from the beginning of the process right through to evaluation, using feedback and communication throughout using an open action-oriented approach; initiating a perspective change; and committing to the transformation of co-creation into a real-life process.

Practical implications

Overall, learning about underlying principles, process initiation, implementation and facilitation of cocreation were areas identified to be included within a co-creation training programme. This can be applied through the framework of enabling change, advocating for co-creative processes, mediating through partnership, communication, leadership, assessment, planning, implementation, evaluation and research, ethical values, and knowledge of co-creative processes.

Originality/value

This study provides novel findings on the competencies needed for health promoting professionals to embed co-creative processes within their practice, and the key concerns that professionals with a position to mediate co-creation have in transferring the abstract term of co-creation into a real-world practice. 


\section{Background}

The field of health promotion has undertaken the challenge of "enabling people to increase control over and improve their health" (WHO, 1986, p1) with citizen's active engagement as a priority. Strong advocacy for citizen participation and engagement, participatory research designs and translational research are the cornerstones of efficient strategies to reduce health inequalities and to focus on the determinants of health based on solidarity and social transformations (Darlington and Masson, 2019). More specifically to the field of health promotion, improving citizen participation seems crucial at policy level with governance for health going beyond just including expert opinion (Kickbusch and Gleicher, 2014). The recent COVID-19 pandemic has shown the importance of participatory approaches in health promotion to enhance the uptake and adhesion to policy-level strategies (Jansen et al., 2008; Jansson, Fosse and Tillgren, 2011).

The World Health Organization (2002, p10) defines participation as "a process by which people are enabled to become actively and genuinely involved in defining the issues of concern to them, in making decisions about factors that affect their lives, in formulating and implementing policies, in planning, developing and delivering services and in taking action to achieve change". Community capacity building is one of the tracks to improve the achievements of health promotion programmes and strategies along such participatory lines (Labonte et al., 2002). However, the issue of how each player and knowledge is equally recognized creates challenges to promoting pathways to citizen engagement, particularly when reflecting on health-related issues.

In recent years, one of the popular strategies to increase citizen participation has been to promote "co-creation". The concept of co-creation originated in business management (Prahalad and Ramaswamy, 2000, 2004) and originally referred to a participatory process where customers, brands and businesses actively engage in interactive relationships to create on-demand and made-to-order products. The dialogue within this participatory process stimulates the exchange of knowledge to solve issues of mutual interest to meet needs and expectations (Pinar et al., 2011; Ribeiro, Tavares and Costa, 2016). This business co-creation concept has been introduced and adapted to the education sector (Pinar et al., 2011; Ribes-Giner et al., 2016; Voorberg et al., 2015; Whitehead et al., 2003; Carvalho et al. 2020) and to the health sector (World Health Organization, 2013; Voorberg, Bekkers and Tummers, 2015; Dean, Griffin and Kulczynski, 2016; Greenhalgh et al., 2016; den Boer, Nieboer and Cramm, 2017; Ramírez and García-Peñalvo, 2018). In both contexts, students (Pinar et al., 2011; Carvalho et al., 2020) and patients/clients (Greenhalgh et al., 2016; den Boer, Nieboer and Cramm, 2017) are the 'customers' (i.e. targeted end-users) in the co-creation process. In health promotion research, the use of co-creation is flourishing in some countries. This is especially occurring at local levels where additional resources are needed alongside scarcity of public funds and the need for sustainability (Torfing et al., 2016). The EU Commission has embraced this need because modern societal demands are too complex to be met by the public sector alone ${ }^{1}$. This emphasis placed by the EU Commission on co-creation is visible, in particular, in the European Public Employment Services (PES) Network, where flexibility, organizational responsiveness, creativity and cooperation with partners were emphasised. A paradigm shift occurred, from a simple business model of providing services to customer-centric organizations, where customer satisfaction is of strategic importance and

\footnotetext{
${ }^{1}$ Horizon 2020 programme focusing on; "Europe in a changing world - inclusive, innovative and reflective Societies $\gg$
} 
co-creation was advocated as an appropriate approach to increase customer satisfaction and facilitate necessary social innovation (European Commission, 2016, 2019a, 2019b). Co-creation is a shared process of problem formulation and problem solving that will upscale solutions to complex societal problems (Torfing, Røiseland and Sørensen, 2016). The anticipated benefits of co-creation include social cohesion, democratic participation as well as the design of more effective and relevant solutions to increasingly complex societal problems (Torfing, Røiseland and Sørensen, 2016).

Nonetheless, a major shortcoming is the blurred outlines and often interchangeably used terms between co-creation and other types of collaboration (Barthe and Queinnec, 1999; World Health Organization, 2002). Many definitions can be found, which include characteristics of the relationship between stakeholders, joint activity, joint achievements (Bovaird and Loeffler, 2012), as well as coexisting concepts such as 'co-creation' and 'co-production', which are often used interchangeably (Torfing, Røiseland and Sørensen, 2016). A parallel can be made with stakeholder participation, which can be modelled in different ways. Hart's ladder of participation (Hart, 1992) sets the focus on the involvement in the initiation of a project and the decisions made to implement it, while Heritage and Dooris propose a ladder of community participation which illustrates the different levels of control, participants' action and modes of such achievements (adapted from Brager and Specht, 1973; in Heritage \& Dooris, 2009). The term co-creation is used inconsistently, carrying different meanings from consultation to partnership and collaboration (Darlington et al., 2017). This lack of clear guidance on defining and thus promoting co-creation leads to heterogeneous participatory practices (Griebler et al., 2017). In the worst-case scenario, so-called co-creation could even be perceived to mean mere consultation, which would potentially set the grounds for tokenistic manipulation. Co-creation has developed as a new paradigm in management literature, with the objective of companies and customers to create value through the interaction between suppliers and customers for the development of new business opportunities (Galvagno \& Dalli, 2014). Following the same shifting paradigm, patient engagement in the planning, development, and analysis of health care has been assumed as a vehicle for maintaining the sustainability of the National Health Service (Armstrong et al. 2013; Hardyman, Daunt, \& Kitchener, 2015). Therefore, the role of patients is also extending beyond being passive recipients of healthcare and even to becoming active participants in their own care, to engaging in innovation and co-creation by taking part in an active dialogue, which occurs within cocreation. Patients are considered equal partners of organizations and health providers, and the focus is set on areas of interest to all parties (Janamian, Crossland, \& Wells, 2016). In this sense, in this research we argue that co-creation involves a transdisciplinary team which has to include end users and professionals who have a "formal responsibility" in the process. It is based on the shared understanding of a situation, the creation of a shared language, dialog, the combination and mutualization of skills and interdependence, and involves the shared negotiation of goals. The underlying objective of the process is to initiate a process of change leading to a new prosperity.

Professionals from all sectors should be involved in health promoting community capacity building strategies and strengthened citizen participation (while being citizens themselves too) (Dempsey et al., 2011). Professionals have the potential to support the development of community skills and knowledge, yet they need specific competencies to do so. Being able to apply these community skills is important for translating policy, theory and research into actionable and sustainable global health promotion and growth (Dempsey et al., 2011). Core competencies that have already been identified include catalysing change, developing leadership, and building partnerships. Professional competency is constructed during professional activity. Such activity, which takes place in a social context, results from cognitive pathways and the motivation of professionals, and of the social 
value of the result expected from the task. To some extent, professional competency can be viewed as a capacity to adapt to new situations and solve complex problems (Albero and Nagels, 2011). Yet, the issue of what professionals' competencies are needed to promote co-creative processes underpinned by partnership and collaboration (not tokenistic consultation) still need to be identified. This also includes the need to address the types of skills needed to promote co-creation within communities, so the processes are not just led by professionals, but all citizens feel engaged in the ability to co-create.

Following Trickett's (2011) argument that researchers must engage with professionals and stakeholders to understand and conceptualise community interventions, our group of researchers from Denmark, France, Portugal, and The United Kingdom aimed to identify the competencies health promotion professionals need to promote co-creation in communities with an underlying health promoting view. Based on this data collection, the CCW training course material was co-constructed in the following four training themes and modules: 1) Creating a common understanding of cocreation, 2) Initiating the co-creation process through collaborative problem formulation and evaluation, 3) Managing the co-creation process and 4) Dissemination and communication of the cocreation process and its's results. Our goal was to develop a training programme for health promoting professionals from the health, education, and social sectors to develop co-creative processes in their community. Therefore, this paper will be focused on the first part of the research project, which was developed to answer the following: what competencies do health promotion professionals need to support co-creation processes in communities? What competencies do health promotion professionals think communities need to engage in co-creation?

\section{METHODOLOGY}

\subsection{Knowledge claim}

This study was undertaken within an ERASMUS+ co-creation project in welfare sectors (EC project number: 2016-1-DK01-KA202-022342). The pragmatic (Creswell, 2003) perspective used for this study follows the argument of Lansang and Dennis (2004), who call attention to the relevance of "research capacity building", whereby scientific knowledge is co-constructed to best fit field priorities, and researchers are free to use all relevant approaches to best meet their purpose. Our intention was to unpack and document professional knowledge and practices of co-creation in natural settings, in order to focus on professionals' views of co-creation and what their needs are in terms of competency development (Reeves et al., 2013). Focusing on stakeholders' knowledge and experience was a means to enable the translation of findings into practice (Woolf, 2008).

\subsection{Participants}

The focus of this study was set on the professionals who promote or in a position to promote, mediate and support co-creation in communities, which we refer to as Co-creation Mediators (CoMeds). Within the scope of the ERASMUS+ co-creation project, the CoMeds would assume the role of integrating and/or disseminating the future CCW training course, which was created taking into account the knowledge gained from the CoMeds. CoMeds were recruited across Denmark, France, Portugal, and the United Kingdom (UK). In each country, different samples of CoMeds were selected, depending on the national context of each group of researchers. 
Table 1 shows an overview of the participants.

Table 1 - participants in each country

\begin{tabular}{|c|c|c|c|c|}
\hline Country & $\begin{array}{l}\text { Type of } \\
\text { sampling }\end{array}$ & $\begin{array}{l}\text { Scope of } \\
\text { samples }\end{array}$ & Social Sector & $\begin{array}{l}\text { Number of } \\
\text { participants }\end{array}$ \\
\hline \multirow[t]{3}{*}{ Denmark } & \multirow[t]{3}{*}{ Purposeful } & \multirow[t]{3}{*}{ National } & $\begin{array}{l}\text { The Youth and Young, Elderly and Handicap } \\
\text { Employment and Social Affairs }\end{array}$ & 22 \\
\hline & & & School and Education Sector & 5 \\
\hline & & & $\begin{array}{l}\text { Administrative and Planning Departments } \\
\text { of Local Government }\end{array}$ & 9 \\
\hline \multirow[t]{5}{*}{ France } & \multirow[t]{5}{*}{ Purposeful } & \multirow[t]{5}{*}{ National } & $\begin{array}{l}\text { Social Design and Co-creation Network } \\
\text { (NW) }\end{array}$ & 3 \\
\hline & & & Health education and promotion NW & 2 \\
\hline & & & $\begin{array}{l}\text { Community health promoting centre for } \\
\text { ageing migrants }\end{array}$ & 2 \\
\hline & & & $\begin{array}{l}\text { higher education lecturer specialized in } \\
\text { health education, sustainable development } \\
\text { education and health promotion }\end{array}$ & 3 \\
\hline & & & $\begin{array}{l}\text { School health promotion professionals } \\
\text { (school nurses, teachers, teaching } \\
\text { assistants, social workers, community } \\
\text { workers, researchers, project managers) }\end{array}$ & 46 \\
\hline \multirow[t]{4}{*}{ Portugal } & \multirow[t]{4}{*}{ Purposeful } & \multirow[t]{4}{*}{ Regional } & $\begin{array}{l}\text { City Council - Department of Culture and } \\
\text { Education }\end{array}$ & 2 \\
\hline & & & Municipal Hospital & 1 \\
\hline & & & $\begin{array}{l}\text { Five Foster Care Residences (Residence } \\
\text { carers, psychologists, teachers, social } \\
\text { workers, education superior technicians } \\
\text { and socioeducational animators) }\end{array}$ & 29 \\
\hline & & & $\begin{array}{l}\text { Three Schools (teachers, health promoting } \\
\text { school coordinators, school psychologists, } \\
\text { school principals) }\end{array}$ & 12 \\
\hline UK & Purposeful & National & $\begin{array}{l}\text { Four organizations that provide health- } \\
\text { related services across local, regional, and } \\
\text { national levels (key people in charge of co- } \\
\text { creative or collaborative processes with the } \\
\text { public) }\end{array}$ & 5 \\
\hline
\end{tabular}

\subsection{Data collection}

Qualitative methods were used to collect the meaning and views of health promoting professionals (Creswell, 2003; Cohen, Manion and Morrison, 2018). The standpoint chosen is that of ethnographic research which focuses on the accounts of people of their own contexts and practices, using a range of tools and methods to fit the contexts, the unstructured aspect being accepted and encouraged (Reeves et al., 2013). Each research team had regular contact with their CoMeds for a whole year and 
a half to complete this study. This included to apply one (Denmark, Portugal, UK) or several sequential data collection instruments (France) and to return the results to the respondents to discuss the implications of the obtained results for the construction and implementation of the CCW training. Oral or written consent was obtained in France and Denmark and Ethical Committee approval was obtained in the U.K. and Portugal. In all countries, confidentiality, anonymity, non-deceptive practice and minimization of possible harm in data collection and analysis were assumed as ethical principles. An unstructured topic guide was developed to ensure that all researchers covered the same topics regarding their current setting, level of co-creative processes, their view of co-creation and how they would like to use co-creation, followed by the main topic of what competences participants would need to co-create with stakeholders and what communities need to engage in co-creation. Depending on their context, and opportunities with the CoMeds, each research team chose the most appropriate data collection tool. However, although there are specific questions for each context, there was a set of open-ended questions, which are analysed in this article, that were placed in the same way in all contexts, regardless of the data collection instrument that was used. This decision was taken to control the limitations that could have arisen associated with the application of different data collection instruments in different contexts. The Danish team used an open-ended process mapping questionnaire, the Portuguese team used focus groups, The UK team used semi-structured in-depth telephone interviews, and the French team used an open-ended questionnaire, unstructured interviews and creative activities producing documents and pictures as creative artefacts as data (Anastacio et al., 2019).

\subsection{Data analysis and analytical framework}

All data collected were transcribed and analysed using the analytical framework of incidental learning to pinpoint competencies (i.e. professionals learn while doing and people identify learning opportunities themselves) (Marsick and Watkins, 2001). Shilton's definition of competency was used: "a combination of attributes such as knowledge, abilities, skills and attitudes which enable an individual to perform a set of tasks to an appropriate standard" (Dempsey et al., 2011, p. 9). Content analysis was conducted on the data (Hsieh and Shannon, 2005) in two phases. In the first phase, data were categorised using an inductive category development method (Hsieh and Shannon, 2005). All open-ended responses, regardless of the data collection instrument, were transcribed verbatim.

Feedback from partner researchers on the categories and items derived from the analysis was given during a joint working session. The second round of analysis was carried out by the group to refine the final categories. When there was doubt about the category in which certain information should be placed, its interpretation was discussed. If no consensus was reached, the information was not categorized, as it was considered ambiguous information. In this article, the final results will be presented by country, regardless of the frequency with which they emerged in each research context, because our aim is to discuss all novel findings, regardless of the intensity with which they emerged in each country.

\section{Results}

\subsection{Incentives and added value of co-creation:}

In the UK, using co-creation was seen as an opportunity to extend reach and involvement of activities to be more inclusive to seldom heard groups and ensure that existing provision is inclusive. In so doing, 
CoMeds hoped to be more consistent in ensuring whole communities are involved because currently closer relationships occur with some local health partners than others. French participants emphasized that co-creation is about "giving a special place to practice-based knowledge or citizen knowledge in our professional practice". The whole points are not just about co-creating the service improvement, but also the engagement method itself "not just about providing facility for patients, but they often come with their partner, and they can be enrolled as well. We seek evaluation, support, and feedback from them as well. We ask patients to complete an evaluation form and ask if their relatives want to complete one as well. That's then looked at by the team. If possible, we try and implement what they have suggested" (UK participant). Co-creation processes were hoped to initiate training activities using a variety of innovative formats with the aim to support social change based on the needs and expectations of the end-users.

Another respondent explained that local services support, develop and launch initiatives in the community, making a difference in the people's health and well-being. Co-creation processes may help to improve projects to be developed with the local community. To some participants, co-creation was a means to address new needs, for example, in one community they were faced with the new situation of having to improve family support, both in terms of prevention and of positive parenting. Community workers were expected to mediate with the families, therefore they are expected to have training in the domain of parental education and/or involvement, as well as for the education of young children.

CoMeds highlighted the novelty of the co-creation concept as well as its similarity with networking and working in partnerships. Another important point raised by the Portuguese participants was to improve interdisciplinarity and interprofessionalism to achieve better results with projects and interventions by using co-creation. They believed the co-creation process might help to improve projects to be developed with the local community without reinventing the wheel and avoiding time-consuming interventions. A respondent stated that the interdisciplinary component of interventions is important to respond to the needs of beneficiaries. The participant also said that "when these skills are shared and, above all, when they are received by the children and primary caregivers, they end up enhancing children's and young people's comfort and well-being" (Portuguese participant). French participants also mentioned strengthening their local network because of professional development in co-creation and advocating for co-creation and high-level participatory methods.

However, one of the key aspects questioned by Danish participants was the value of co-creation to the- CoMeds people taking part in co-creation. There was a concern that co-creation is just another way of implementing budget cut downs in communities.

\subsection{Key principles to engage in and implement co-creation}

Respondents from all countries expressed the essential need to create a common understanding of co-creation. Danish participants suggested that CoMeds need to promote a common understanding of co-creation among different sectors and professional backgrounds, so that good results and experiences could be spread from one sector to another.

Additionally, clear agreements and transparency in the co-creative processes, and how to develop such agreements are important. To co-produce new solutions, all partners need to know how and what kind of influence they can have in the process "I think you need capacity on both sides, and resources" (Danish participant). Methods to shift from an expert approach to citizen knowledge and its use in professional practice are very much needed. This is done "by involving community members from the 
start and throughout the project, and by imagining work methodologies which are adapted to them" (French participant). Danish participants emphasized the fact that CoMeds should shift from defining citizens by their needs to a more resource-focused approach and partnership-based solutions based on strong communication with community members.

The majority of Portuguese CoMeds stated that to support co-creation in their working settings they need to be able to engage key stakeholders from the very beginning of the collaborative problem formulation process. In this sense, and as an example, they indicated that one of the aims of teachers' professional development in co-creation was to be able to use students' perceptions about their wellbeing at school. A discussion of students' perceptions can be used as a starting point for co-creation, implementation, and evaluation of a school-based well-being project involving key-people in their local community. In the U.K., feedback from stakeholders was also put forward as important: "With our volunteer group we meet with them once a year and ask for feedback from them, how do you feel about the current service? Do you think our meet and greet is adequate for new patients coming in? Sometimes patients will feed back to our volunteer group instead of our clinical staff because they don't want to say anything that is deemed negative, and we try and tap into that as a resource as well."

With regards to the tools which could be relevant for co-creation, participants from the U.K. indicated that social media can be used to involve patients and staff simultaneously in improvement activities. Social media can also be useful to see what conversations are emerging, rather than one setting the topic. French participants suggested that CoMeds should implement co-creation techniques and tools that involve a variety of stakeholders (NGOs, Universities...). They also mentioned being able to create and test tools stakeholders had created for themselves.

\subsection{Learning suggestions from and for CoMeds}

Suggestions for learning were put forward: learning about what CoMeds could do to promote co-creation processes; learning about methods to implicate end-users and other stakeholders from the start; learning about how to adapt existing methods or methods they use already; project management methods and tools could also be part of the learning. Informants also expressed the need for support on how to give feedback to those involved in co-creation on how they have contributed and the difference they have made, or if no changes occurred following their input, then explain why. The resources provided should be intuitive to use and include stories. They should be universal for all stakeholders (not separate ones for each group).

Professionals would also need to enable citizens to understand health services, the language used and politics that comes with it "Usually if you address the public and ask them "what do you want to do about this?", you get a blank stare, it is too technical, but if you say, "we're thinking of doing this, what do you think?" That's very different. Occasionally someone will rise and say, "why don't you do this?" But I would say that most members of the public don't understand how health services are commissioned, the way they are provided, the amount of money that is involved. It's quite removed" (UK participant). This highlights the educational need to facilitate the early stages of the co-creation process to identify needs, problems, and resources before moving forwards to the solution finding stage (rather than proposing a solution and getting feedback). Danish participants also highlighted the need for methods on defining and understanding the problems to be solved, and how to "see documentation as a good friend and in a meaningful way".

According to Portuguese participants, CoMeds are expected to learn about a pedagogical strategy to interact with their public and improve their skills, namely communication and 
assertiveness. Resources are needed to improve partnership communications. Also, Danish participants pointed out that CoMeds should learn how to work with empowerment.

Another key learning is how to measure the impact and added value of co-creation to dispose of a more rigorous evaluation of the impact of the changes they implemented through co-creation. It would be useful to be able to measure how changes affect uptake and adherence to co-creation and understand what other added values could be measured. Danish participants emphasized the definition of success criteria and evaluation design in co-creation processes was one a key issue, along with how to identify end-objectives and results, and how to carry out the process-oriented evaluation. CoMeds would also need to learn about methods to progress to collect more compelling narrative and evidence about the productivity impact.

\section{a. Suggested competencies for CoMeds}

The overall point of view of the CoMeds in the four countries was that a core anchoring of essential professional competences is needed, having in mind that working together with other sectors and professions requires a very strong sense of professionalism. In the U.K., developing co-creative competencies was viewed as a mechanism for creating time, capacity, and energy for focusing on cocreation to develop resources and local expertise. Indeed, CoMeds need to reflect and identify what their expectations are, what community members' expectations are, as well as frame the working space: "Being reactive to patient's needs and requests is very positive. However, sometimes it's trying to manage patient's expectations as well, of what they will get out of the service. Sometimes patients come with very high expectations or frustrations, and it's then that we need to try and work with our primary colleagues, which can be more of a challenge" (UK Participant).

CoMeds wanted strong professional skills to facilitate co-creation and ensure that all those involved in the co-creation process work together to identify the problems and create feasible solutions for all: "Would be useful to have facilitation skills. Important for patients to see something because of their input. Looking at a pathway of where we start off. Sometimes it is not possible to put suggestions in place, for example financial restrictions. That constraint is very tight these days. Facilitation training in that." (UK participant). The expectations of all parties are central as well as the working space available between all participants in the co-creation process.

CoMeds suggested the following as important attributes and attitudes, knowledge, abilities and skills (Dempsey et al., 2011, p. 9):

\section{Attributes and attitudes}

The specific attributes and attitudes needed to implement and support co-creation include: openness, embracing differences, creativity, realization, provision of skills, facilitating an understanding of operations, learning to give up, pushing the limits, let oneself be surprised, resilience, making processes fluid, audacity, agility, efficiency, accepting the wealth of others, putting one's skills to contribution to work for a project, to question oneselves, being open to the opinion of the other, an obligation to be open to the opinion of the other, meeting the needs of citizens, distancing from one's own representations of "the other person", a process that requires effort and which one may not be aware of, increasing one's skills, creativity, taking risks, daring, fostering skills, making things easier, building self-confidence, working in good relational conditions: listening, embracing, taking a step back, sending feedback. 
An important personal attribute is the ability to commit oneself and be aware of the importance of personal competences (as much as the professional competences) when transforming co-creation from an abstract term to a "real life" process. This can include shifting from one's own point of view; being able to ask: "What might be the best for you?; being humble; being curious; creativity and courage; being able to turn the perspective from looking for well-known (professional) solutions to new possibilities.

\section{Knowledge}

Knowledge, evidence, and research are also the roots of the development of co-creation. The respondents put forward the following items as the necessary knowledge they would need to be able to support co-creation as CoMeds (Figure 1).

\section{CoMeds}

would need to learn about

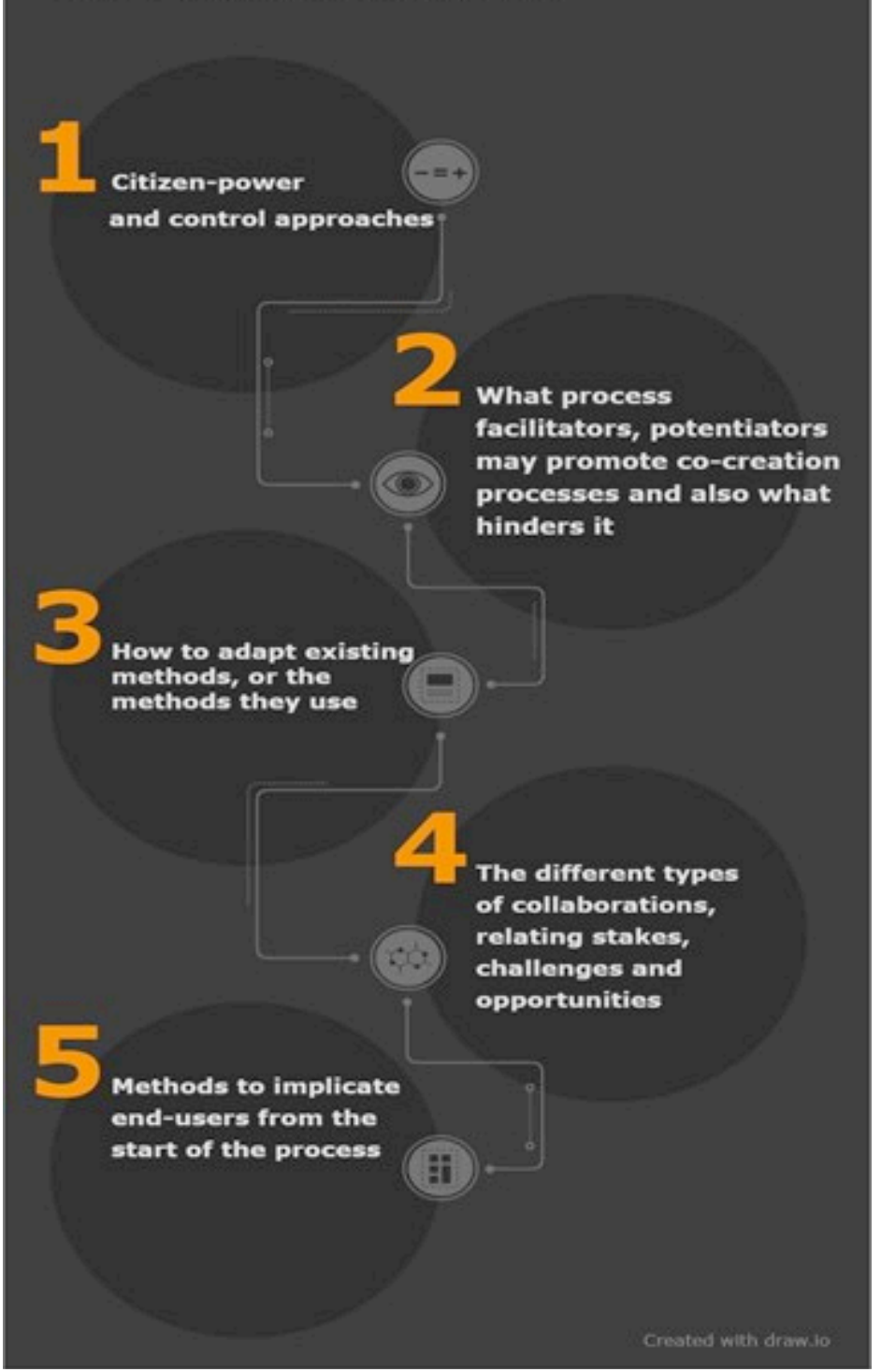

Figure 1: Necessary knowledge CoMeds would need to support co-creation 
Knowledge CoMeds need to initiate and maintain co-creation in their workplace was organised in a sequential, interconnected and flexible plan, which respects the order in which these needs globally emerged in CoMeds from all countries when they remembered or imagined how to initiate and develop co-creation in their professional contexts.

The first need of knowledge is categorized under the label "Citizen power and control approaches" to answer concerns of CoMeds, such as "I think it is not difficult for key people to join the group, what is difficult is for them to participate without fear when people with different positions are in the same group, for example the educational assistant at the school library defending a different idea from the school principal" (PT).

The second area of knowledge is about "What process facilitators, potentiators may promote cocreation processes and also what hinders it". Evidence on the facilitating factors and barriers associated with co-creation in different contexts was collected. As barriers emerged, for example, the difficulty of maintaining open dialogues with the group (PT, FR), not getting everyone in the group to feel committed to the co-creation processes (FR), situations of conflict within the group that imply need mediation (PT), people do not want to participate because they think they don't have time (UK, PT). The support of leaders (PT), have skills as a group facilitator (DK, FR, UK), have knowledge about co-creation (FR) emerged as facilitating factors. However, overall it was observed that there was little awareness of these factors, the need to analyse them in context and to think of possible ways to overcome barriers, even before they arise.

The third area of knowledge is "How to adapt existing methods, or the methods they use". The intention of the co-creation processes is not to create a rupture with pre-existing methods, but to reflect on how to enhance them, integrate them or abandoning them in a critical and reflexive way to promote collaborative work and shared narratives. It was observed that globally, even active participant-centred practices were often uncooperative and more focused on individual than collective assessment. For example, in Portugal, role-play activities, theatre forum, and simulated case studies were very common, but aimed at evaluating the personal and social skills of each participant involved, as well as increasing his/her knowledge. Therefore, emerged the necessity to work with the CoMeds "The different types of collaborations, relating stakes, challenges and opportunities" and the "Methods to implicate end-users from the start of the process".

\section{Abilities and skills}

Communication skills were put forward as essential. Also, professionals supporting co-creation need to be able to deconstruct representations and personal projected knowledge and facilitate collective redefinition. This requires reflexivity, especially on one's attitude. Participants highlighted that reflexivity should be associated with curiosity, the incline to make discoveries, and the ability to assemble knowledge and talents together. Skills are very much related to professional identity and the goals set for the project. Professionals are expected to act rather than "react" to specific limitations and choose, for example, to change the timeframe and the scale of the project. The following skills were explicitly mentioned as key:

- Communication skills

- Skills to present their thoughts on a subject

- Skills to create dialogue

- Project management skills

- Skills to develop the motivation of volunteers

- Skills to identify possibilities and run them in a co-creative and participatory way 
- Skills to engage with end users more

- Skills to create an "open" method to elaborate action-oriented training

- Skills to support processes

The CoMeds also specifically addressed the need for skills to initiate a perspective change; the skills to engage in and create relationships, e.g., with volunteers and parents in day-care centres.

Table 2 provides an overview of the specific competences needed to implement and support cocreation.

Table 2. The specific competences needed to implement and support co-creation

\begin{tabular}{|c|c|c|c|c|}
\hline & DK & $\mathrm{FR}$ & PT & UK \\
\hline \multicolumn{5}{|l|}{ Personal competences } \\
\hline Openness & $x$ & $\mathrm{x}$ & $x$ & $\mathrm{x}$ \\
\hline Shifting from one's own point of view & $\mathrm{X}$ & $\mathrm{x}$ & $\mathrm{X}$ & $\mathrm{x}$ \\
\hline Being able to ask: "What might be the best for you"? & & $\mathrm{x}$ & & \\
\hline Being humble & & $x$ & $x$ & \\
\hline Being curious & $\mathrm{x}$ & $\mathrm{x}$ & $\mathrm{x}$ & $x$ \\
\hline Resilience & & $\mathrm{x}$ & & $\mathrm{X}$ \\
\hline Creativity & $\mathrm{x}$ & $\mathrm{x}$ & $x$ & $\mathrm{X}$ \\
\hline Building self-confidence & $\mathrm{x}$ & $\mathrm{x}$ & $\mathrm{x}$ & $\mathrm{x}$ \\
\hline Audacity & & & & $\mathrm{x}$ \\
\hline Agility & & $\mathrm{x}$ & & \\
\hline Efficiency & & & & $\mathrm{x}$ \\
\hline \multicolumn{5}{|l|}{ Procedural competences to promote open dialogue } \\
\hline Listening & $\mathrm{x}$ & $\mathrm{x}$ & $\mathrm{x}$ & $x$ \\
\hline Embracing differences & $\mathrm{x}$ & $\mathrm{x}$ & $x$ & $\mathrm{X}$ \\
\hline Being open to the opinion of the other & $\mathrm{x}$ & $\mathrm{x}$ & $x$ & $\mathrm{X}$ \\
\hline Pushing the limits & & $\mathrm{x}$ & & \\
\hline Learning to give up & & $\mathrm{x}$ & & \\
\hline Let oneself be surprised & & $\mathrm{x}$ & & \\
\hline Accepting the wealth of others & & & & $x$ \\
\hline Working in good relational conditions & $\mathrm{x}$ & $\mathrm{X}$ & $\mathrm{X}$ & $\mathrm{x}$ \\
\hline \multicolumn{5}{|l|}{ Procedural competences regarding co-creation } \\
\hline Meeting the needs of citizens & $\mathrm{x}$ & $\mathrm{x}$ & $x$ & $\mathrm{x}$ \\
\hline Facilitating an understanding of operations & $\mathrm{x}$ & $\mathrm{x}$ & $x$ & $\mathrm{x}$ \\
\hline Making processes fluid & $x$ & $\mathrm{X}$ & & \\
\hline Be aware of the effort co-creation process requires & & $\mathrm{x}$ & $x$ & \\
\hline Taking a step back & & & & $\mathrm{x}$ \\
\hline Embracing change & $\mathrm{x}$ & $\mathrm{X}$ & $\mathrm{X}$ & $\mathrm{x}$ \\
\hline Putting one's skills to contribution to work for a project & $\mathrm{X}$ & $\mathrm{x}$ & & \\
\hline Fostering skills/ Provision of skills & $\mathrm{x}$ & $\mathrm{X}$ & $\mathrm{X}$ & $x$ \\
\hline Making things easier & & & & $x$ \\
\hline Realization & & $\mathrm{x}$ & & \\
\hline \multicolumn{5}{|l|}{ Reflection and coaching competences } \\
\hline To question one selves & & $\mathrm{x}$ & $\mathrm{x}$ & \\
\hline
\end{tabular}




\begin{tabular}{|l|l|l|l|l|}
\hline Sending feedback & & $X$ & $X$ & \\
\hline $\begin{array}{c}\text { Distancing from one's own representations of "the other } \\
\text { person" }\end{array}$ & & $X$ & & \\
\hline
\end{tabular}

Note: DK - Denmark; FR - France; PT - Portugal

Overall, the following areas of learning were identified and categorized within the phases of the project management cycle (Table 3).

Table 3: Areas of learning which should be included in a training programme to promote co-creation in communities and related questions raised during the study

\begin{tabular}{|c|c|c|}
\hline \multicolumn{2}{|c|}{ UNDERLYING PRINCIPLES TO CO-CREATION } & \multirow{2}{*}{$\begin{array}{l}\text { QUESTIONS RAISED DURING THE RESEARCH } \\
\text { How to avoid fighting for your own } \\
\text { professionalism and the right to define the } \\
\text { problem - hereby also the solution? }\end{array}$} \\
\hline $\begin{array}{l}\text { Promoting } \\
\text { stakeholders' } \\
\text { sense of } \\
\text { legitimacy in the } \\
\text { process }\end{array}$ & $\begin{array}{l}\text { Promoting Equality in decision- } \\
\text { making } \\
\text { Promoting Equality in different types } \\
\text { of knowledge (expert vs individuals' } \\
\text { experiences) } \\
\text { Learning to "step back" }\end{array}$ & \\
\hline $\begin{array}{l}\text { Promoting } \\
\text { empowerment }\end{array}$ & $\begin{array}{l}\text { Knowing about Citizen-power and } \\
\text { control approaches } \\
\text { Promoting ownership } \\
\text { Including citizens in decision-making } \\
\text { processes } \\
\text { Learning about methods to implicate } \\
\text { end-users from the start }\end{array}$ & $\begin{array}{l}\text { How to involve citizens more in strategic } \\
\text { decisions. }\end{array}$ \\
\hline \multicolumn{3}{|c|}{ INITIATING THE PROCESS OF CO-CREATION } \\
\hline $\begin{array}{l}\text { Creating a } \\
\text { shared } \\
\text { understanding } \\
\text { of co-creation } \\
\text { processes }\end{array}$ & $\begin{array}{l}\text { Identifying the stakes for all } \\
\text { stakeholders } \\
\text { Shifting from consultation and } \\
\text { tokenism }\end{array}$ & $\begin{array}{l}\text { How can co-creation be implemented in different } \\
\text { sectors but still be understood within the same } \\
\text { frame? }\end{array}$ \\
\hline $\begin{array}{l}\text { Starting where } \\
\text { people are }\end{array}$ & $\begin{array}{l}\begin{array}{l}\text { Pinpointing } \\
\text { constraints, } \\
\text { challenges, }\end{array} \\
\text { clarifying the meaning of the process } \\
\text { for citizens }\end{array}$ & $\begin{array}{l}\text { What are the mutual expectations from each of } \\
\text { the partners? Formal as well as informal }\end{array}$ \\
\hline \multicolumn{3}{|c|}{ IMPLEMENTING THE PROCESS OF CO-CREATION } \\
\hline $\begin{array}{l}\text { Collaborative } \\
\text { problem-solving }\end{array}$ & $\begin{array}{l}\text { Mentoring } \\
\text { Supporting active voluntary groups } \\
\text { Welcoming "out-of-the-box- } \\
\text { thinking" } \\
\text { Promoting creative thinking } \\
\text { methods, Co-design methods } \\
\text { Learning to ask questions rather than } \\
\text { look for answers. } \\
\text { Being able to pinpoint ideas and } \\
\text { knowledge from selected evidence, } \\
\text { and adapting it to local context }\end{array}$ & $\begin{array}{l}\text { How to define and understand the problems to be } \\
\text { solved? } \\
\text { What is the product supposed to solve? }\end{array}$ \\
\hline
\end{tabular}




\begin{tabular}{|c|c|c|}
\hline & $\begin{array}{l}\text { Turning challenges into opportunities } \\
\text { for out-of-the-box thinking }\end{array}$ & \\
\hline $\begin{array}{l}\text { Supporting } \\
\text { project } \\
\text { development }\end{array}$ & $\begin{array}{l}\text { Project management skills } \\
\text { Knowledge of different types of } \\
\text { collaborations and relating stakes, } \\
\text { challenges, and opportunities } \\
\text { Promoting motivation } \\
\text { Creating adequate and tailored } \\
\text { evaluation frameworks } \\
\text { Promoting new partnerships } \\
\text { Learning about how to adapt existing } \\
\text { methods, or methods they use }\end{array}$ & $\begin{array}{l}\text { How to upscale and activate the change agents in } \\
\text { co creation? }\end{array}$ \\
\hline $\begin{array}{l}\text { Sharing the } \\
\text { creation of tools }\end{array}$ & $\begin{array}{l}\text { Promoting equality in needs analysis } \\
\text { Understanding the stakes for all } \\
\text { citizens involved } \\
\text { Promoting creative thinking methods }\end{array}$ & \\
\hline \multicolumn{3}{|c|}{ FACILITATING THE PROCESS OF CO-CREATION } \\
\hline $\begin{array}{l}\text { Promoting } \\
\text { mediation } \\
\text { competences }\end{array}$ & $\begin{array}{l}\text { Considering the overarching context, } \\
\text { constraints, and needs (policy, } \\
\text { professional practice, social context } \\
\text { etc...) } \\
\text { Supporting the creation of adequate } \\
\text { and tailored tools and solutions } \\
\text { Shifting from an expert posture to a } \\
\text { process facilitator } \\
\text { Understanding the stakes relating to } \\
\text { the different sectors } \\
\text { Developing } \\
\text { communication skills } \\
\text { Being humble, curious } \\
\text { Changing perspective } \\
\text { Learning about what process } \\
\text { facilitator, potentiators may promote } \\
\text { co-creation processes }\end{array}$ & $\begin{array}{l}\text { How to communicate to open for new solutions } \\
\text { and not just look for what we know we can } \\
\text { present from a professional perspective? } \\
\text { How can teachers be less experts and more } \\
\text { facilitators? }\end{array}$ \\
\hline $\begin{array}{l}\text { Disseminating } \\
\text { the approach }\end{array}$ & $\begin{array}{l}\text { To address variability among } \\
\text { stakeholders (horizontal } \\
\text { relationships) and within the } \\
\text { overarching systems of policies } \\
\text { (vertical relationships) } \\
\text { Improving consistency and } \\
\text { developing a shared vision of co- } \\
\text { creation processes } \\
\text { Supporting advocacy for co-creation } \\
\text { to promote the value and potential of } \\
\text { the process }\end{array}$ & $\begin{array}{l}\text { How does the investment impact on outcomes of } \\
\text { interest and social return of investment? }\end{array}$ \\
\hline $\begin{array}{l}\text { Using existing } \\
\text { resources }\end{array}$ & $\begin{array}{l}\text { Drawing from Evidence-based } \\
\text { knowledge } \\
\text { Using New technologies } \\
\text { Finding funding }\end{array}$ & $\begin{array}{l}\text { Lots of financial support possibilities - can or must } \\
\text { they be (more) coordinated? }\end{array}$ \\
\hline
\end{tabular}


Promoting institutional and political

support

Identifying and using existing tools

Being able to select adequate

resources and adapting them to local

context

Supporting the use of resources

\section{Discussion}

The conclusions presented in this study result from the crossed conclusions of four different contexts with different degrees of complexity and data collection instruments. Recognizing these limitations and concerns about generalization in case study research, the conclusions are presented as suggested for qualitative empirical research, in which assertions and generalizations are constructed, not as certainties but as interpretations with some built-in uncertainty (Creswell, 2003).

\subsection{Key competences to carry out co-creation processes in communities}

Based on Shilton's definition of competency as including "a combination of attributes such as knowledge, abilities, skills and attitudes which enable an individual to perform a set of tasks to an appropriate standard" (Dempsey et al., 2011, p. 9) we identified two different types of professional competencies which are needed to support co-creation processes in communities: i) competencies related to the processes of development of co-creation in the communities and their monitoring, impact assessment and dissemination; and ii) personal competencies based on attitudes and attributes. Regarding the first type of competencies, in all countries, the following main competencies necessary for a co-creation mediator in health promotion were identified: 1) being critical regarding citizen-power and control approaches; 2) being able to apply processes to promote co-creation, namely facilitating the early stages of the co-creation process to identify needs, problems and resources; applying project management methods and tools; and giving feedback to participants in the process of co-creation; 3 ) being able to adapt existing methods, or the methods they use to promote co-creation processes; 4) being able to create different types of collaborations relating stakes, challenges and opportunities; 5 ) being able to implicate end-users from the start of the co-creation process and; 6) applying methods and techniques to measure the impact and added value of cocreation (e.g. how to collect more compelling narrative and evidence about the productivity impact), and how changes affect uptake and adherence of participants to the process. The ability to reflect individually and collectively on practices to facilitate the collective redefinition of the action process were also considered very important. The attitudes and attributes identified as essential were related to the promotion of open dialogues (namely friendliness, empathy, confidence, respect - e.g. openness, embracing differences, being open to the opinion of the other -, cohesion and listening) within co-creation processes, that require the development of competencies such as creativity, learning to give up, pushing the limits, let oneself be surprised, audacity, creativity, taking risks, daring.

Our findings relate and can be categorized based on the CompHp Competencies (Dempsey et al., 2011; Barry et al., 2012; Battel-Kirk and Barry, 2020) to link co-creation practices to the specifics of health promotion competences: 
1) Enabling change: for individuals, groups, communities, and organizations to engage in cocreative and participatory approaches to implement health promotion projects.

Enabling change is about promoting stakeholders' sense of legitimacy in the process of co-creation. CoMeds should make sure they promote community empowerment and ownership. Citizens must be included in the decision-making processes. This competency is about making sure participation levels shift from tokenism and consultation to citizen power modes. This competency needs to be developed in CoMeds, as above referred (see section Knowledge).

2) Advocating for co-creative processes: to advocate with, and on behalf of, individuals, communities, and organizations to upscale levels of citizen participation and improve health promotion actions.

It is essential to disseminate and advocate for co-creative processes with a view to promote the value and potential of the process. Advocating for co-creation also means finding funding. Advocacy should also be focused on institutional and political levels as strong institutional and political support are needed. Also, a key point is for CoMeds to address the existing variability among stakeholders (horizontal relationships) and within the overarching systems of policies (vertical relationships). Volunteers from different social and economic backgrounds have different motives, which are very different from one another. Therefore, they must be treated and motivated differently.

Giving feedback to those involved in co-creation on how they have contributed and the difference they have made, or if no changes occurred following their input, then explain why, is also one of the CoMeds missions. Moreover, one of the issues raised was the need to embed co-creation in education rather than bolt on this way of thinking later in professional/citizen life.

3) Mediating through partnership: to work collaboratively across disciplines, sectors, and partners in an equitable process of co-creation to develop health promotion action.

Participants emphasized that one of the key terms to be used regardless of professional background is "voluntary work" to describe how citizens and private sector agents collaborate with the public welfare sector. The good effect of volunteering must be obvious and logic for all parties. Developing dialogues and approaches to co-create, as well as creating an alliance, citizens and professionals are a key element of success. Additionally, clear agreements and transparency in the co-creative processes are important. The process deployed to develop such agreements would need to be addressed in a CoMed training programme. When co-producing new solutions, all involved in co-creation need to reflect on how and what kind of influence they can have in the process. Therefore, it is not just about co-creating the service improvement but also the engagement method itself. The CoMed's role, then, includes to know how to "step back" and to demonstrate facilitative and mentoring skills while also acknowledging that they might need to be part of the co-creative process. The CoMeds should welcome "out-of-thebox-thinking" and promote new partnerships.

\section{4) Communication: to communicate effectively, using appropriate techniques and technologies} for diverse audiences.

One of the main features in developing co-creation is to enable community members to exercise, develop, and maintain the use of constructive communication skills. The CoMed would have to demonstrate mediation competences to support co-created projects. Furthermore, social media and new communication technologies can be used to see what initial conversations are emerging, rather than the CoMed setting the topic themselves. The resources provided should be intuitive to use and 
include stories that community members can relate to. They should be universal for all involved in the co-creation. A point was made about the need to improve the resources available to improve partnership communications.

5) Leadership: to contribute to the development of a shared vision and strategic direction for co-creation.

Respondents expressed the need to have a common understanding of co-creation. It is essential to create a shared understanding of co-creation processes and to clarify the meaning and improve the consistency of the process for citizens. The CoMed must clearly understand the stakes relating to different professional sectors and the collaboration between professional sectors. An element of concern for potential difficulties was also highlighted. Different co-creation approaches are used in the different sectors and co-creation is inconsistently used across the different local/regional areas. A suggestion was made to improve the consistency of practices across the country. The lack of consistency in the implementation of co-creative processes and what they mean and entail is a shortcoming that would have to be overcome by the CoMed. The irregular implication of citizen stakeholders, which was pointed out as an issue, was explained by day-to-day problems and concerns, as well as also constraints (health issues, social issues...). CoMeds would also need to enable citizens to understand how health, education and social services work, the language they used and the politics that comes with it. They would need to be able to identify and use existing tools, select adequate resources, and adapt them to the local context. An additional point was made on promoting the community members' motivation to use co-creation based on their different incentives to take part in the process.

6) Assessment: to conduct assessment of needs and assets in partnership with stakeholders, in the context of the political, economic, social, cultural, environmental, behavioural, and biological determinants that promote or compromise co-creation.

CoMeds would have to be able to identify the stakes for all stakeholders to start where people are. Being able to pinpoint expectations, constraints, challenges, opportunities, and resources is one of the expected competencies for a CoMed. The whole process is about understanding the stakes for all the citizens involved. The overarching context, constraints, and needs (policy, professional practice, social context etc...) should be the base for the CoMed's support. This means that the CoMed would have to master co-creation methods and tools to be able to adapt and select the right way forward in a specific context.

\section{7) Planning: to develop measurable goals and objectives for co-creation based on assessment} of needs and assets in partnership with stakeholders.

Not much was said about planning other than it involved supporting project development. This gap in knowledge was made evident during this study. We considered it a pressing need for training as participants did not consider planning an important issue in co-creation and they showed little knowledge about it. Bearing in mind the aspects described above about the importance of project management, as an essential element of planning, training would have to integrate planning and provide key knowledge about project management.

8) Implementation: to implement effective and efficient, culturally sensitive, and ethical cocreation with stakeholders. 
CoMeds should support the use of collaborative problem-solving, creative thinking methods, and codesign methods. They should enable communities to share the creation of adequate and tailored tools and solutions, as well as adequate and tailored evaluation frameworks. New technologies could be useful in this process. Additionally, respondents identified the need to share good co-creation practices, as they thought it was lacking. Another suggestion was made to prepare a method catalogue starting from a political, professional and citizen perspective in collaboration with NGOs and associations, e.g. "Methods in citizen meeting". However, as pointed out by one of our respondents, one size does not fit all!

9) Evaluation and research: to use appropriate evaluation and research methods, in partnership with stakeholders, to determine the reach, impact and effectiveness of cocreated health promotion action.

According to our respondents, it is important to draw from evidence-based knowledge. Success criteria and evaluation designs should encompass results and process-evaluation of co-creation processes. The increased sense of belonging, which resulted from higher levels of participation, was put forward because of co-creation. Respondents highlighted that they would need support about measuring the impact and added value of co-creation and to dispose of a more rigorous evaluation framework to assess the impact of the changes they implemented through co-creation. It would be useful to be able to measure how such changes affect uptake and adherence to co-creation and understand what other added values could be measured. They would like to progress to collect more compelling narrative and evidence about the impact of co-creation.

10) Ethical values: The ethical values and principles included in co-creation (equity and social justice, respect for the autonomy and choice of both individuals and groups, and collaborative and consultative ways of working).

According to the respondents, co-creation should take place based on the following underlying values and principles: equality in decision-making; equality in different types of knowledge (expert vs individuals' experiences); equality in needs analysis; shifting from an expert posture to a process facilitator; being humble, curious; changing perspective.

11) Knowledge of co-creative processes and additional knowledge needed: a CoMed health promotion practitioner draws on a multidisciplinary knowledge base of the core concepts, principles, theory, and research of co-creation in health promotion and its application in practice.

The development of adaptation skills can contribute to enabling professionals and communities to engage in innovations and / or customize and adapt existing solutions to fit their own purposes and needs (Rogers, 2010). In this respect, the development of professional skills to accompany the shift is not considered an end but as a tool for communities to expand and build up their own emancipatory competencies, especially in the field of health (Israel et al., 1998). This approach is about giving communities the means to design and implement solutions themselves and be the agent of change in a 'bottom-up' perspective (Laverack and Labonte, 2000). The CoMed's role is thus to support this process by providing space and resource, rather than to take on the role of promoter of a solution targeting the community. Community capacity-building of developing skills, resources, and sustainable commitments to increase and sustain health benefits (Hawe et al., 2000) is, however, often 
underestimated. One of the reasons is that available funding often prioritizes population or topiccentred programmes and projects (Hawe et al., 2000). However, the professional practice can be a lever to amplify community capacity, aiming to place the generation of knowledge in a dynamic and transdisciplinary continuum involving all institutional, professional and community stakeholders (Dankwa-Mullan et al., 2010). The idea is not to reinvent the wheel, but instead to design educational training to address these unmet competency-based needs to develop a common and sustainable capacity for all those relevant to the involvement of co-creation, including those at the organisational level, professional service delivery and receivers of services, such as students, patients and public members (Marsick and Watkins, 2001).

\subsection{Implications of this study to increase the quality of the CoMed training programme}

Based on the findings from this research, training should include formal and non-formal education based on the sharing of experience and knowledge of the participants, drawing for the richness of "complementarity" (Glasman, 2005 in Bier, 2010) as well as incidental learning. Three conditions are, however, necessary for the development of this type of learning: reflexivity, proactivity, and creativity. We propose that the underlying perspective to training should be that of "organizational learning theory" as described by Levitt and March (1988), who argue that the learning of organizations occurs through experience and its interpretation (Levitt and March, 1988). The reflective capacity, also in focus in experiential learning (Kolb, 1984), is "constant in those who face singular situations, difficult cases, dilemmas, new problems" (Perrenoud, 2001, p44). According to Nonaka, the 'spiral of learning' finds its starting point in individual learning, which extends to the group and then to the wider level of the community and even of a country or group of countries, thanks to the "continuous interaction between individuals constituting these larger entities" (Bray, 2007, p6).

The development of community capacity standards has shown to require a practice-based approach (Allegrante et al., 2009). We argue that the same approach is needed for the development of co-creation practices. Transformational and transdisciplinary research maintains and fosters a close relationship with the stakeholders and professionals affected by and engaged in health promotion, and that participatory research designs are particularly important to address health inequalities (Dankwa-Mullan et al., 2010). Participatory research methods could facilitate the uptake of research findings into health promotion practice and enhance interventions' reach and adoption (Glasgow, Lichtenstein and Marcus, 2003).

\subsection{Linking back to existing participatory approaches}

The competences put forward by the CoMeds relate to the concept of community competence as identified by Cottrell in 1976. Community competence can be described in terms of how stakeholders collaborate in identifying problems and needs in the community, work based on a consensus as to how to prioritize issues, set goals and design ways to achieve them, and implement solutions collaboratively and effectively (Eng and Parker, 1994). The process described by CoMeds could also be related to community empowerment, as described by Israel and collaborators (1994)'s, who suggest that a gain in understanding and control, which involves collective problem solving will, 
promote beneficial action (Ruderman, 2000). "An empowered community is one in which individuals and organizations apply their skills and resources in collective efforts to meet their respective needs. Through such participation, individuals and organizations within an empowered community provide enhanced support for each other, address conflicts within the community, and gain increased influence and control over the quality of life in their community. Similar to an empowered organization, an empowered community has the ability to influence decisions and changes in the larger social system." (Israel et al., 1994, p153). Community empowerment is the process of enabling citizens to gain understanding and decision-power over the issues that concern them. When aiming to develop community capacity, it is key to improve stakeholder and community members' participation and leadership, develop problem assessment skills and increase analytical skills (Laverack and Labonte, 2000; Labonte et al., 2002). The community organizing approach (Crisp, Swerissen, \& Duckett, 2000) consists of drawing from existing resources in the community, and developing awareness, skills and leadership within the community. This approach also involves creating opportunities for the community members to gain skills and knowledge. Community members become active drivers of change, as they recognize their own capacity and resources to trigger and manage such change. Ruderman et al $(2000$, p.3) provide us with the dimensions of community competence as "commitment, self-other awareness and clarity of situational definitions (accurate perceptions of divergent viewpoints), articulateness, communication, conflict containment and accommodation, participation, management of relations with the larger society, and machinery for facilitating participant interaction and decision making. Social support and leadership development have also been added in some conceptualizations."

\section{CONCLUSION}

This study provides novel findings on the competencies needed for the professional development of health promoting professionals to embed co-creative processes within their practices and communities. The findings are of trans-national importance spanning welfare contexts across Denmark, Portugal, France, and UK. Competencies identified highlight key concerns that professionals with a position to mediate co-creation have in transferring the abstract term of co-creation in realworld practice. Overall, learning about underlying principles, process initiation, implementation and facilitation of co-creation were identified as areas that need to be included within a co-creation training programme and a set of co-creation tools that can be used in practice. This can be applied in the future through the framework developed from these findings of enabling change, advocating for co-creative processes, mediating through partnership, communication, leadership, assessment, planning, implementation, evaluation and research, ethical values, and knowledge of co-creative processes.

\section{References}

Albero, B. and Nagels, M. (2011) 'La compétence en formation Entre instrumentalisation de la notion et instrumentation de I' activité', Education et Formation, 296, pp. 13-30.

Allegrante, J. P. et al. (2009) 'Domains of core competency, standards, and quality assurance for building global capacity in health promotion: The Galway Consensus Conference Statement', Health Education \& Behavior, 36(3), pp. 476-482. doi: 10.1177/1090198109333950. 
Anastacio, Z. et al. (2019) Co-creating Welfare - Training Course Material Preparing Professionals to Co-Create Welfare Solutions with Citizens. Braga, Portugal: Universidade do Minho. Instituto de Educação Centro de Investigação em Estudos da Criança.

Armstrong, N., G. Herbert, E.-L. Aveling, M. Dixon-Woods, and G. Martin. 2013. "Optimizing Patient Involvement in Quality Improvement." Health Expectations 16 (3): e36-e47.

Barry, M. M. et al. (2012) CompHP: Developing Competencies and Professional Standards for Health Promotion Capacity Building in Europe: The CompHP Project Handbook. Paris: International Union for Health Promotion and Education.

Barthe, B. and Queinnec, Y. (1999) 'Terminologie et perspectives d'analyse du travail collectif en ergonomie', L'année psychologique, 99(4), pp. 663-686. doi: 10.3406/psy.1999.28501.

Battel-Kirk, B. and Barry, M. M. (2020) 'Evaluating progress in the uptake and impact of Health Promotion competencies in Europe', Health Promotion International, 35(4), pp. 779-789. doi: 10.1093/heapro/daz068.

Bier, B. (2010) 'Des villes éducatrices ou l'utopie du " territoire apprenant "', Informations sociales, $\mathrm{n}^{\circ}$ 161(5), p. 118. doi: 10.3917/inso.161.0118.

den Boer, J., Nieboer, A. P. and Cramm, J. M. (2017) 'A cross-sectional study investigating patientcentred care, co-creation of care, well-being and job satisfaction among nurses', Journal of Nursing Management, 25(7), pp. 577-584. doi: 10.1111/jonm.12496.

Bovaird, T. and Loeffler, E. (2012) 'From Engagement to Co-production: The Contribution of Users and Communities to Outcomes and Public Value', Voluntas, 23(4), pp. 1119-1138. doi: 10.1007/s11266012-9309-6.

Bray, D. A. (2007) 'Literature Review - Knowledge Management Research at the Organizational Level', SSRN Electronic Journal, (1), pp. 1-18. doi: 10.2139/ssrn.991169.

Cohen, L., Manion, L. and Morrison, K. (2018) Research Methods in Education. Routledge. Oxon: Taylor \& Francis.

Creswell, J. W. (2003) 'Research design: Qualitative, quantitative, and mixed method approaches, 2nd Edition', in. Thousand Oaks: Sage Publications.

Crisp, B. R., Swerissen, H. and Duckett, S. J. (2000) 'Four approaches to capacity building in health: consequences for measurement and accountability', Health promotion international, 15(2), pp. 99107. doi: 10.1093/heapro/15.2.99.

Darlington, E. J. et al. (2017) State of Play and Needs analysis report. Saint-Etienne.

Darlington, E. J. and Masson, J. (2019) 'Challenges and perspectives on how to articulate social inequalities, equity, citizenship and solidarity in health promotion', Education, Santé, Sociétés, 6(1).

Dean, A. M., Griffin, M. and Kulczynski, A. (2016) 'Applying Service Logic to Education: The Co-creation Experience and Value Outcomes', Procedia - Social and Behavioral Sciences. Elsevier B.V., 224(August 2015), pp. 325-331. doi: 10.1016/j.sbspro.2016.05.383.

Dempsey, M. C. et al. (2011) Literature Review Developing Competencies for Health Promotion. Paris. Eng, E. and Parker, E. (1994) 'Measuring Community Competence in the Mississippi Delta: The Interface between Program Evaluation and Empowerment', Health Education Quarterly, 21(2), pp. 199-220.

European Commission (2019a). Annual Report - European Network of Public Employment Services (PES), Luxembourg. 
European Commission (2019b). European Network of Public Employment Services: Cocreation of services Thematic Review Workshop on Co-creation of services. Brussels: European Commission

European Commission (2016): Measuring Customer Satisfaction with PES. Increasing PES Effectiveness by Meeting Customer Needs - Analytical Paper, Luxembourg. Author Lukasz Sienkiewic

Galvagno, Marco \& Dalli, Daniele (2014). Theory of value co-creation: a systematic literature review. Managing Service Quality, Vol. 24 No., 6, 2014, pp. 643-683

Glasgow, R. E., Lichtenstein, E. and Marcus, A. C. (2003) 'Why don't we see more translation of health promotion research to practice? Rethinking the efficacy-to-effectiveness transition', American Journal of Public Health, 93(8), pp. 1261-1267. Available at: http://ajph.aphapublications.org/doi/abs/10.2105/AJPH.93.8.1261 (Accessed: 20 April 2014).

Greenhalgh, T. et al. (2016) 'Achieving Research Impact Through Co-creation in Community-Based Health Services: Literature Review and Case Study', Milbank Quarterly, 94(2), pp. 392-429. doi: 10.1111/1468-0009.12197.

Griebler, U. et al. (2017) 'Effects of student participation in school health promotion: A systematic review', Health Promotion International, 32(2), pp. 195-206. doi: 10.1093/heapro/dat090.

Hardyman W, Daunt KL, Kitchener M. Value co-creation through patient engagement in health care: a micro-level approach and research agenda. PublicManage Rev. 2015;17(1):90-107.

Hart, R. A. (1992) 'Children's participation: from Tokenism to citizenship', UNICEF International Child Development Centre. doi: 88-85401-05-8.

Hawe, P. et al. (2000) Indicators to Help with capacity building in Health Promotion. NSW Health. Edited by Australian Center for Health Promotion. Sydney: State Health Publication. Available at: http://www.bvsde.paho.org/bvsacd/cd64/capbuild.pdf.

Heritage, Z. and Dooris, M. (2009) 'Community participation and empowerment in Healthy Cities', Health Promotion International, 24(Supplement 1), pp. 45-55. doi: 10.1093/heapro/dap054.

Hsieh, H. and Shannon, S. (2005) 'Three approaches to qualitative content analysis', Qualitative Health Research, 15(9), pp. 1277-88. doi: 10.1177/1049732305276687.

Israel, B. A. et al. (1994) 'Health Education and Community Empowerment: Conceptualizing and Measuring Perceptions of Individual, Organizational, and Community Control', Health Education \& Behavior, 21(2), pp. 149-170. doi: 10.1177/109019819402100203.

Israel, B. A. et al. (1998) 'Review of community-based research: assessing partnership approaches to improve public health', Annual review of public health, 19(1), pp. 173-202.

Janamian T, Crossland L, Wells L. On the road to value co-creation in health care: the role of consumers in defining the destination, planning the journey and sharing the drive. Med J Aust. 2016;204(suppl 7):S12-S14.

Jansen, M. W. J. et al. (2008) 'Collaboration between practice, policy and research in local public health in the Netherlands', Health Policy, 86(2-3), pp. 295-307. doi: 10.1016/j.healthpol.2007.11.005.

Jansson, E., Fosse, E. and Tillgren, P. (2011) 'National public health policy in a local contextImplementation in two Swedish municipalities', Health Policy. Elsevier Ireland Ltd, 103(2-3), pp. 219227. doi: 10.1016/j.healthpol.2011.08.013.

Kickbusch, I. and Gleicher, D. (2014) 'Smart governance for health and well-being: the evidence', p. 172. doi: 10.1017/СВ09781107415324.004.

Kolb, D. (1984) Experiential learning: experience as the source of learning and development. Englewood Cliffs, New Jersey: Prentice-Hall, Inc. 
Labonte, R. et al. (2002) 'Community Capacity Building: A parallel track for health promotion programs', Canadian Journal of Public Health, 93(3), pp. 181-182.

Laverack, G. and Labonte, R. (2000) 'A planning framework for community empowerment goals within health promotion', Health Policy And Planning, 15(3), pp. 255-262. doi: 10.1093/heapol/15.3.255.

Levitt, B. and March, J. G. (1988) 'Organizational Learning', Annual Review of Sociology, 14(1), pp. 319338. doi: 10.1146/annurev.so.14.080188.001535.

Marsick, V. J. and Watkins, K. E. (2001) 'Informal and Incidental Learning', New Directions for Adult and Continuing Education, 2001(89), p. 25. doi: 10.1002/ace.5.

Perrenoud, P. (2001) 'Mettre la pratique réflexive au centre du projet de formation', Cahiers Pédagogiques, (390), pp. 42-45.

Pinar, M. et al. (2011) 'Utilizing the brand ecosystem framework in designing branding strategies for higher education', International Journal of Educational Management, 25(7), pp. 724-739. doi: 10.1108/09513541111172126.

Prahalad, C. K. and Ramaswamy, V. (2000) 'Co-Opting Customer Competence", Harvard Business Review, 78(1), pp. 79-90. Available at: https://hbr.org/2000/01/co-opting-customer-competence.

Prahalad, C. K. and Ramaswamy, V. (2004) 'Co-creation experiences: The next practice in value creation', Journal of Interactive Marketing, 18(3), pp. 5-14. doi: 10.1002/dir.20015.

Ramírez, M. S. and García-Peñalvo, F. J. (2018) ‘Co-creation and open innovation: Systematic literature review', Comunicar, 26(54), pp. 9-18. doi: 10.3916/C54-2018-01.

Reeves, S. et al. (2013) 'Ethnography in qualitative educational research: AMEE Guide No. 80.', Medical teacher, 35(8), pp. e1365-79. doi: 10.3109/0142159X.2013.804977.

Ribeiro, H. C. M., Tavares, V. C. miranda and Costa, B. K. (2016) 'COCRIAÇÃO DE VALOR: UMA BIBLIOMETRIA DE 2000 A 2014', Revista Eletrônica de Estratégia \& Negócios, 9(1), p. 118. doi: 10.19177/reen.v9e12016118-151.

Ribes-Giner, G., Perello-Marín, M. R. and Díaz, O. P. (2016) 'Co-creation Impacts on Student Behavior', Procedia - Social and Behavioral Sciences. The Author(s), 228(June), pp. 72-77. doi: 10.1016/j.sbspro.2016.07.011.

Rogers, E. M. (2010) Diffusion of Innovations, 4th Edition. Available at: http://books.google.com/books?hl=fr\&lr=\&id=v1ii4QsB7jlC\&pgis=1 (Accessed: 23 January 2015).

Ruderman, M. (2000) 'Resource guide to concepts and methods for community-based and collaborative problem solving', Baltimore, MD: Johns Hopkins Bloomberg School of Public Health, Women's and Children's Health Policy Center. Available at: http://citeseerx.ist.psu.edu/viewdoc/download?doi=10.1.1.127.9401\&rep=rep1\&type=pdf

(Accessed: 30 January 2014).

Torfing, J., Røiseland, A. and Sørensen, E. (2016) 'Transforming the public sector into an arena for cocreation: Barriers, drivers, benefits and ways forward', Administration \& Society, (August).

Voorberg, W. H., Bekkers, V. J. J. M. and Tummers, L. G. (2015) 'A Systematic Review of Co-Creation and Co-Production: Embarking on the social innovation journey', Public Management Review, 17(9), pp. 1333-1357. doi: 10.1080/14719037.2014.930505.

Whitehead, D., Taket, A. and Smith, P. (2003) 'Action research in health promotion', Health Education Journal, 62(1), pp. 5-22. doi: 10.1177/001789690306200102.

WHO (1986) Ottawa Charter for Health promotion. Ottawa.

Woolf, S. H. (2008) 'The meaning of translational research and why it matters', Jama, 299(2), pp. 211213. Available at: http://jama.jamanetwork.com/article.aspx?articleid=1149350 (Accessed: 20 April 2014). 
World Health Organization (2002) 'Community participation in local health and sustainable development Approaches and techniques', World Health Organization, p. 91.

World Health Organization (2013) Health 2020: a European policy framework supporting action across government and society for health and well-being. Copenhagen. doi: 9789289002790. 